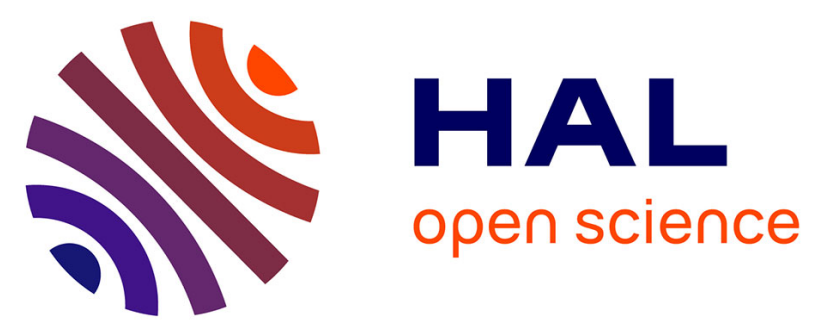

\title{
Investigating Key Antecedents of Customer Satisfaction in B2B Information Service Firms
}

\author{
Vikas Kumar, Archana Kumari, Ximing Ruan, Jose Arturo Garza-Reyes, \\ Supalak Akkaranggoon
}

\section{- To cite this version:}

Vikas Kumar, Archana Kumari, Ximing Ruan, Jose Arturo Garza-Reyes, Supalak Akkaranggoon. Investigating Key Antecedents of Customer Satisfaction in B2B Information Service Firms. 13th Conference on e-Business, e-Services and e-Society (I3E), Nov 2014, Sanya, China. pp.327-337, 10.1007/9783-662-45526-5_30. hal-01342163

\section{HAL Id: hal-01342163 \\ https://inria.hal.science/hal-01342163}

Submitted on 5 Jul 2016

HAL is a multi-disciplinary open access archive for the deposit and dissemination of scientific research documents, whether they are published or not. The documents may come from teaching and research institutions in France or abroad, or from public or private research centers.
L'archive ouverte pluridisciplinaire HAL, est destinée au dépôt et à la diffusion de documents scientifiques de niveau recherche, publiés ou non, émanant des établissements d'enseignement et de recherche français ou étrangers, des laboratoires publics ou privés. 


\title{
Investigating Key Antecedents of Customer Satisfaction in B2B information Service Firms
}

\author{
Vikas Kumar ${ }^{1} \bowtie$, Archana Kumari ${ }^{1}$, Ximing Ruan ${ }^{1}$, Jose Arturo Garza-Reyes ${ }^{2}$, and \\ Supalak Akkaranggoon ${ }^{3}$ \\ 1 Bristol Business School, University of the West of England, Bristol, BS16 1QY, UK \\ \{Vikas.Kumar, Archana.Kumari, Ximing.Ruan\}@uwe.ac.uk \\ 2 Centre for Supply Chain Improvement, The University of Derby, Derby, DE22 1GB, UK \\ J.Reyes@derby.ac.uk \\ 3 Khon Kaen University, Nong Khai Campus, 112 M. 7 A., Muang, Nong Khai, 43000, \\ Thailand \\ supakk@kku.ac.th
}

\begin{abstract}
Service sector has grown significantly over the years and now is one of the major contributors of the Gross Domestic Product (GDP) of most of the developed and developing economies. Within the service sector, information economy has grown significantly with the rapid developments in the Internet and Communication Technologies (ICTs). However, the research so far has focused on the manufacturing sector rather than the service sector. This paper, therefore, aims to fill this void by testing the service management and Service Quality (SERVQUAL) theories in Businesses to Business (B2B) information services context. An empirical investigation with secondary data is carried out to explore the relationship between three key antecedents of Customer Satisfaction (CS) namely; Functional Service Quality (FSQ), Technical Service Quality (TSQ) and Corporate Image (CI). This re-search also aims to investigate the interrelationship between the three key antecedents of customer satisfaction. The findings show that FSQ, TSQ, and CI are positively correlated with customer satisfaction. Results also show that CI is positively correlated with TSQ and FSQ.
\end{abstract}

Keywords: Information Services, FSQ, TSQ, Corporate Image, Customer Satisfaction, B2B, Service Management e-business, e-government.

\section{Introduction}

Over the years, the manufacturing sector has dominated the world economy; however, the world economy is now slowly transforming to a service based economy. The growing importance of services to the economy can be realized by the fact that service sector nowadays is a major contributor to the Gross Domestic Product (GDP) of most of the developed and developing nations [1] [2]. For example, the contribution of services to the U.S. GDP is around $80 \%$, UK around $73 \%$, Japan around $74 \%$, France around $73 \%$ and Germany is around $68 \%$ [1] [2] [3]. The growth in service sector is primarily attributed to the rapid advancements and 
implementations of the Internet and Communication Technologies (ICTs). ICT growth has led to the emergence of the information sector as a strong contributor in the service dominant economy. The significance of information economy was firstly highlighted by Machlup [4] and then later by Porat and Rubin [5] who attempted to measure the US information economy. In the late 70s, Porat and Rubin [5] measured the size and structure of the US information economy. Their findings reveal that the information sector contributed to around $46 \%$ of the US Gross National Product (GNP) in 1967. A research by Apte and Nath [6] concluded that the contribution of the information sector to US GNP rose to around 63\% in 1997. The significance of information economy was further verified by [7] and [8], who point out that during the last fifty years, developed or developing economies have evolved from a goods or manufacturing-oriented economy to a service oriented and now have moved on to the information-oriented economy.

Information economy has become integral part of the economy and their contribution cannot be ignored. However, the research so far has primarily focused on the manufacturing sector. In light of the growing significance of information services in the worldwide economy and the lack of enough research evidence, this paper sets out to test some of the service management and SERVQUAL theories in the context of information service settings, particularly, in Business to Business (B2B) information service firms. Literature identifies Service Quality and Corporate Image as key indicators of Customer Satisfaction [9] [10] [11] [12] [13]. Nevertheless, quality is often treated as multidimensional construct in services which can be understood from two main dimensions: Technical Service Quality (TSQ) and Functional Service Quality (FSQ) [8] [9] [14] [15] [16]. Existing literature has identified a number of antecedents of customer satisfaction, such as; quality, trust, dependability, corporate image and waiting time [17] [18] [19]. However, this research will primarily investigate the linkages between three key antecedents of customer satisfaction: Technical Service Quality, Functional Service Quality, and Corporate Image and their impact on customer satisfaction in the context of B2B information service organizations. The choice of three antecedents is restricted by the availability of the secondary data provided by the case organization. In addition, the interrelationship between the three key antecedents of customer satisfaction has not been fully explored in literature and this study aims to also bridge this gap.

The rest of the paper is organized as follows. Next section reviews a number of research papers to set out the context of the research and identify the linkages among the variables. Section 3 delineates the research objectives and proposes the research framework. Section 4 elaborates the research methodology. The findings of the research are presented in section 5. Section 6 concludes this study and sets out the direction for future research

\section{Theoretical Background}

Earlier discussion indicates that with the rapid advancement in ICTs, economy is slowly moving towards a more information based economy. However, very few researchers have looked at the information service sector [1] [2] [6] [7] [8]. Literature also indicates that the growth in information technology, inter-net and web 
technologies has revolutionized the way in which Business to Business (B2B) and Business to Customers (B2C) organizations interact and offer services to their customers [20] [21]. B2B and B2C firms have different characteristics that set them apart from each other, for example, different types of purchases and authorizations; unique contracts, terms, and conditions for different business customers; variety of customer sizes, demands and requirements; and different level of participation in customer's supply chain [8] [22] [23] [24]. Due to these differences, the strategies adopted by B2B and B2C firms vary [25]. A study by Rauyruen and Miller [26] further suggests that $\mathrm{B} 2 \mathrm{~B}$ service providers need to understand the nature and the circumstances of their customers. Therefore, B2B service-providers should pay attention to the quality control of their service delivery systems and must put a lot of effort into creating high-level perception of the service quality [8]. Tang et al. [27] argues that perceived service quality is an important factor in the B2B. This was also noted in the study of Bhappu and Schultze [21], where they found that in the B2B environment, both the relational (soft quality) and operational performance (hard quality) are of prime significance particularly for achieving customer satisfaction. However, apart from the study by Bhappu and Schultze [21] there are limited studies that aim to investigate the significance of the service quality dimensions in the B2B environment [27] [28] [29]. This study, therefore, aims to empirically provide further evidence of the relationship between FSQ, TSQ and Customer Satisfaction in a B2B service setting.

The drivers of customer satisfaction are well highlighted in the operations management literature, which identifies service quality, speed, flexibility, cost, corporate image and dependability as critical drivers [9] [18] [19] [30]. One of the popular frameworks that identify the linkage between quality and customer satisfaction is the service profit chain proposed by Heskett et al. [18]. In brief, it proposes a positive linear relationship between staff satisfaction, service quality and customer satisfaction leading, ultimately, to profitability [16]. Gonzalez et al. [30] also identify perceived service quality as an antecedent of satisfaction. This was also further verified in the work of [2] [19] [31] [32]. These SERVQUAL studies show that a strong link exists between customer satisfaction and service quality. Parasuraman et al. [33] differentiate the service quality construct as Functional Service Quality (FSQ) (doing things nicely) and Technical Service Quality (TSQ) (doing things right). Grönroos [34] suggests that dissatisfaction occurs if expectations are greater than actual performance. As a result, evaluations are not based solely on the outcome of the service, the technical quality; they also involve the process of service delivery or functional quality. A number of published researches emphasize the relationship between the two dimensions of service quality (i.e. technical and functional) and customer satisfaction [16] [35] [36] [37]. A study by Rosenzweig and Roth [38] shows that an interrelationship exists between the two dimensions of service quality, i.e., TSQ and FSQ. They further provide empirical evidence of their impact on profit-ability. Lai and Yang [39] also demonstrate that TSQ affects user satisfaction positively. Apart from the service quality dimensions, corporate image has also emerged as one of the drivers of customer satisfaction and loyalty. Andreassen and Lindestad [40] based on data from 600 individual customers, reported that corporate image impacts customer satisfaction and loyalty. Their study also reports that corporate image impacts customer loyalty directly. This relationship was 
also reported in the study of Martenson [41] where they showed that corporate image is a key driver of customer satisfaction. Cameran et al. [42] in their study of the professional service firms show that corporate image and service quality impacts customer satisfaction. Wu et al. [43] show that higher perceptions of service quality have a positive influence on corporate image. The study also indicates that higher perceptions of corporate image influences customer satisfaction positively. The literature review clearly indicates that service quality dimensions (FSQ and TSQ) and corporate image influence customer satisfaction and customer loyalty positively. Moreover, there is an interrelationship between service quality dimensions (FSQ and TSQ) and corporate image.

The information sector has shown rapid growth in the last few decades and has started showing the dominance in today's economy. The literature review further indicates that FSQ, TSQ, and Corporate Image influences Customer Satisfaction. However, literature investigating these relationships in a B2B information service environment is scarce. Realizing the gap in the literature, this paper sets out to fill this void by empirically investigating the service management and SERVQUAL theories that links these variables together in B2B information services. The next section provides the research framework and propositions to be tested in this research.

\section{Research Model and Propositions}

The literature review highlights that functional service quality (FSQ); technical service quality (TSQ); and corporate image (CI) affect customer satisfaction (CS) and loyalty. This investigation is a confirmatory study which aims to test the findings of service management and SERVQUAL literature in the context of B2B information service settings. This study looks beyond the traditional linkages between these variables and sets out to understand their interrelationships. Apart from highlighting the linkages, this study also stresses that performing well on these dimensions can help B2B information service firms to successfully meet customer satisfaction levels which in the longer run can lead to customer loyalty and ultimately benefit firms to achieve sustainable competitive advantage. The study primarily focuses on identifying the significance of Functional Service Quality, Technical Service Quality, Corporate Image and Customer Satisfaction. The investigation involves assessing these relationships in a large B2B information intensive firm operating in the UK. Customer loyalty is not included in the framework due to the restrictions imposed by the secondary data. This research sets out to test the following relationships in the context of information service settings:

- Functional Service Quality (FSQ) affects Customer Satisfaction

- Technical Service Quality (TSQ) affects Customer Satisfaction

- Corporate Image (CI) affects Customer Satisfaction

- An interrelationship exists between FSQ, TSQ, and CI 


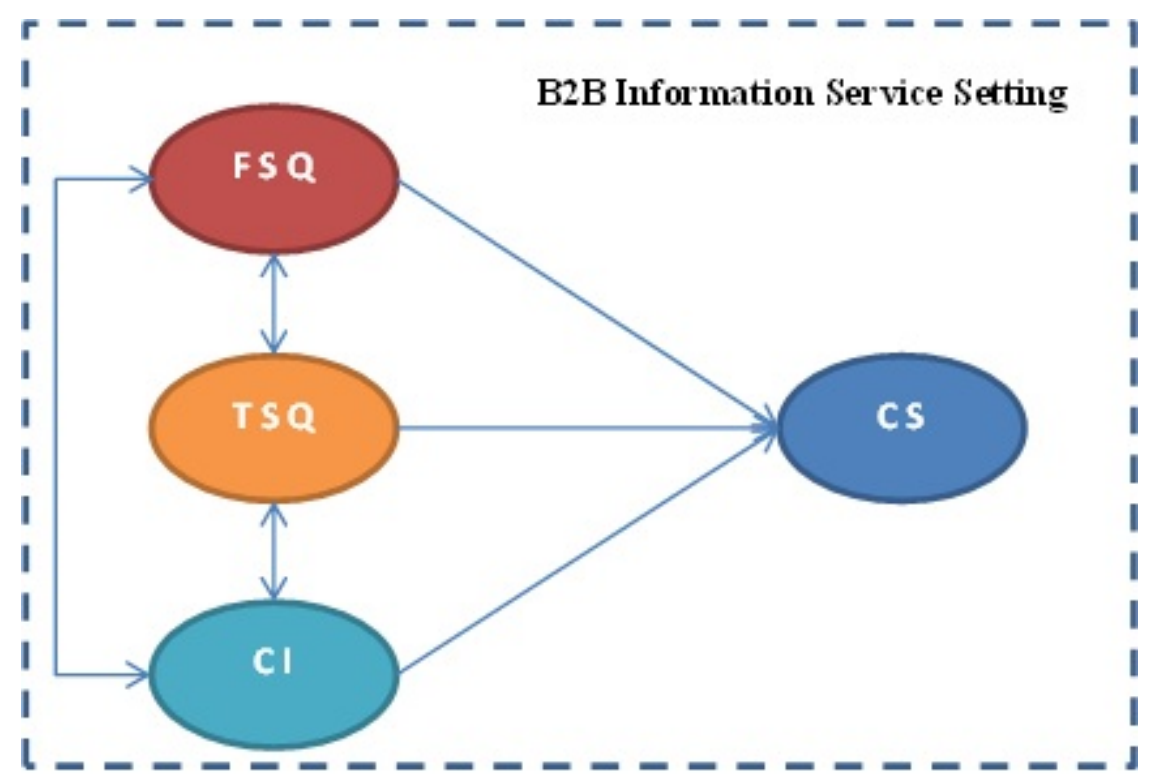

Figure 1. Research Framework

The research framework tested in this research comprises of three key antecedents of customer satisfaction namely, FSQ, TSQ, and CI (see Fig. 1). As mentioned above, the literature review indicates that a number of papers link these individual key indicators with customer satisfaction, however, studies investigating their interrelation-ships in information service setting is limited. The study proposes a number of propositions derived from the framework based on the review of literature. This study sets out to test following propositions:

P1: Functional Service Quality affects with Customer Satisfaction positively

P2: Technical Service Quality affects Customer Satisfaction positively

P3: Corporate Image affects Customer Satisfaction positively

P4: Functional Service Quality and Technical Service Quality are positively correlated

P5: Functional Service Quality and Technical Service Quality are also positively correlated with Corporate Image

The next section elaborates the research methodology and data collection method followed in this research.

\section{$4 \quad$ Research Methodology}

In management research, positivism has traditionally been much more dominant than phenomenology [8], [44], [45]. In this study the selection of the quantitative approach is not motivated by its dominance in management research; rather that the choice has been based purely on the research aims. This research therefore supports the positivist approach. A hypothetico-deductive approach has been followed where the hypotheses 
are constructed and guided by previous theories and later these hypotheses are tested, based on the gathered empirical data, and accepted or rejected as a part of the theorytesting. The explanatory nature of the research demanded that, in order to explore the causality, the variables need to be studied over time. Longitudinal time series data collected over 48 months' time frame was made available for researchers. Secondary data used in this research was collected by the B2B service firm by applying the collection and analysis protocols consistently. Bryman [46] points out that secondary data are usually of high quality, as rigorous sampling procedures are employed and experienced researchers or data collection agencies are involved, following a structured approach and control procedures to ensure the quality of the collected data. Bryman [46] further identifies that it offers the opportunity of longitudinal analysis and is less time-consuming, thus providing more time to the researcher for the data analysis. Thus, this study relies on the secondary longitudinal time series data for the analysis.

This research paper investigates a large information intensive B2B service firm operating in the UK. The case example studied is from the network branch of the B2B power supplier in the UK. The network branch is a distribution company that operates and maintains the electrical supply system for organizations with large energy needs and spends. The network branch currently provides energy to more than 30,000 organisations that together spend over £2bn on electricity and gas. For the B2B network branch the customers are mainly the Small and Medium scale Enterprises (SMEs) and large business firms. The firm offers a range of agreements for their business customers, such as fixed term contract, flexible purchasing contracts and specialist customer contracts. The firm measures and collects data through telephone interviews and surveys to monitor its performance over time. The secondary data set for a 48 months' time frame (48 data points) was made available for this research that comprised monthly measurements of variables considered as proxies for Functional Service Quality, Technical Service Quality, Corporate Image and Customer Satisfaction.

In this research, Functional Service Quality (FSQ) refers to soft quality or relational element of the quality whereas Technical Service Quality (TSQ) is referred as a hard quality or an ability to perform the promised service dependably and accurately, including time commitments [10] [15] [16]. The B2C service firms used a multi-dimensional scale to measure the FSQ and TSQ. The firm did not employ SERVQUAL scale to measure the quality construct. However, the measures used by the firm resemble to some of the items of the SERVQUAL scale including the empathy, access, assurance, and responsiveness dimensions. Corporate Image was also measured on a multi-dimensional scale. How-ever, Customer Satisfaction was measured on a single item scale as an overall satisfaction with the level of services provided. The constructs studied in this study were measured on a 5 point Likert scale and conform to the reliability and validity tests. FSQ, TSQ and CI were finally converted to a single scale item as Cronbach's Alpha value was $>0.70$. The detailed scales of the variables studied are presented below:

FSQ (Cronbach’s Alpha $=0.90)$

FSQ_1: Staff were polite and helpful

FSQ_2: They were able to provide sufficient information about the problem 
FSQ_3: I was able to easily contact them to find out about the problem

TSQ (Cronbach's Alpha $=0.81)$

TSQ1: Overall, how would you rate the non-half hourly bills and billing service?

TSQ2: Overall, how would you rate the non-half hourly meter reading service?

TSQ3: Overall, how would you rate the half hourly statements and invoicing service?

TSQ4: Overall, how would you rate the half hourly meter reading service?

CI (Cronbach’s Alpha = 0.80)

CI. They are well-known

CI. They have a good reputation

CI. They are environmentally responsible

CI. They support local communities

CI. They recognize and reward your loyalty

CI. They offer competitive prices

CS: Overall, how would you rate their level of customer service?

The next section discusses the data analysis findings.

\section{$5 \quad$ Research Findings}

Data analysis firstly involved running a correlation analysis (see Fig. 2). The analysis shows there is a positive correlation (0.615) between functional service quality and customer satisfaction with a significance level of $\mathrm{P}<0.01$. This verifies our first proposition (P1). A positive correlation (0.601) was also evident between technical service quality and customer satisfaction significant at $\mathrm{P}<0.01$ level. This verifies our second proposition (P2). Corporate image was also positively correlated with customer satisfaction (0.478) significant at $\mathrm{P}<0.05$ level. This verified our third proposition (P3). The next step of the analysis was aimed at investigating the interrelationship between the three key antecedents studied in this research. A positive correlation was found between TSQ and CI (0.565) as well as between CI and FSQ (0.687) both significant at $\mathrm{P}<0.01$ level. This verifies our fifth (P5) proposition. Interestingly, no significant correlation (0.310) was found between FSQ and TSQ. Thus, our proposition P4 could not be verified.

\section{Conclusions}

The paper shows that Functional Service Quality (FSQ), Technical Service Quality (TSQ) and Corporate Image (CI) are key antecedents of Customer Satisfaction (CS). The findings are interesting as these relationships were tested in a new context of B2B information services. The outcome shows that for B2B information service firms performing well on both quality dimensions (FSQ and TSQ) is very important to maintain a satisfied customer base. This counter argues some of the SERVQUAL findings (such as Grönroos [9]) that prioritize FSQ over TSQ in achieving customer 
satisfaction by indicating that both dimensions are equally important. This verifies the earlier findings of Bhappu and Schultze [21], who emphasized the significance of both quality dimensions. Findings suggest that failure to meet quality expectations of customers can lead to dissatisfaction and ultimately customers can move on to other competitors. Another important finding of this study is the importance of corporate image in building customer satisfaction. The research also shows that FSQ and TSQ are positively correlated with corporate image thus suggesting an interrelation-ship between these three variables. While the literature tends to treat these three variables independently, the outcome of this research shows that the elements are closely linked. This also suggests that if firms perform well on quality dimensions their corporate image can be improved. However, analysis showed that FSQ and TSQ are not correlated. This is an interesting finding as, first it points out that both quality dimensions are distinct, an argument that has been widely argued in SERVQUAL literature. Secondly, a lack of correlation between these two variables also suggests that performing well on one dimension of service quality not necessarily improves the other dimension. Hence, B2B information service firms must focus on both dimensions of service quality to satisfy their customers. However, more evidence is required before generalizing the relationship between FSQ and TSQ in B2B information service setting.

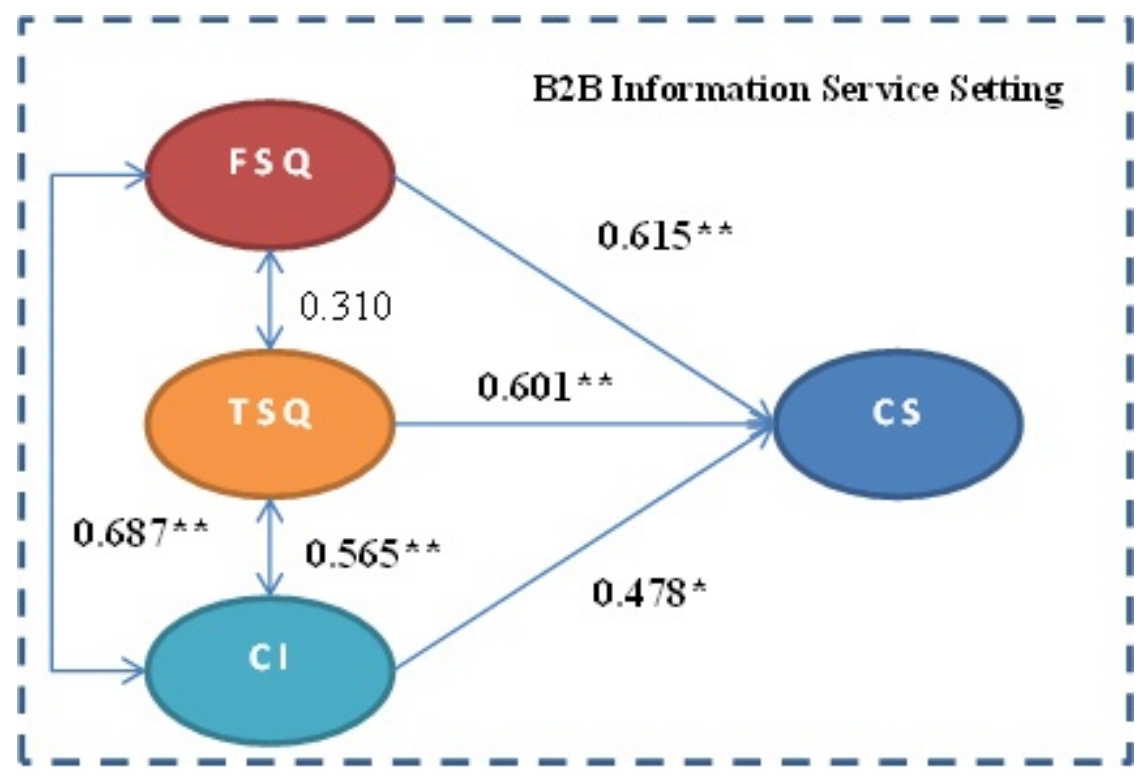

Figure 2. Correlations

It is important to bear in mind that the findings presented in this paper are based on a single case example from a B2B information services context. Therefore, generalizations that we infer are limited to just B2B information services. We also intend to test these relationships using more case examples to support our findings and extend this study further by also investigating these relationships in B2C information services. Looking at these relationships over a longer time frame is also 
vital and this requires alternative methods of research. Longitudinal studies are necessary to test out some cause-effect phenomena.

Future studies should involve testing these relation-ships using more robust statistical methods such as multiple regressions and structural equation modeling in B2C information sector. Additionally, more case examples should be investigated to broaden the generalizations of the findings across the information services sector. Moreover, future studies should also aim to investigate the differences in the relationships among the variables between the SMEs and the large business firms.

\section{References}

1. Lovelock, C. and Wirtz, J.: Services Marketing: People, technology, strategy, 6th Edition, Pearson Prentice Hall, US, (2007)

2. Kumar, V., Kumari, A., Garza-Reyes, J. A., \& Lim, M.: Dependability a Key Element for Achieving Competitive Advantage: A Study of Information Service Firms. In Advances in Production Management Systems, Sustainable Production and Service Supply Chains, Springer Berlin Heidelberg, 493-500 (2013)

3. Paulson, L. D.: Services Science: A New Field for Today's Economy, Industry Trends: Published by the IEEE Computer Society, August 2006, 14-17 (2006)

4. Machlup, F.: The Production and Distribution of Knowledge in the United States, Princeton University Press, Princeton, NJ (1962)

5. Porat, M. U. and Rubin, M. R.: The Information Economy (9 Volumes), OT Special Publication, US Department of Commerce, 77-12 (1-9), Washington, DC (1977)

6. Apte, U. M., and Nath, H. K.: Size, structure and growth of the US information economy, In Managing in the Information Economy, Springer US, 1-28 (2007)

7. Godin, B.: The Information Economy: the History of a Concept through it Measurement, 1949-2005, Project on the History and Sociology of S \& T Statistics Working Paper No. 38, 185 (2008)

8. Kumar, V.: An Empirical Investigation of the Linkage between Dependability, Quality and Customer Satisfaction in Information Intensive Service Firms, Doctoral dissertation, University of Exeter, UK (2011)

9. Grönroos, C.: Service quality: the six criteria of good perceived service quality, review of Business, 9 (3), 10-13 (1988)

10. Newman, K.: Interrogating SERVQUAL: a critical assessment of service quality measurement in a high street retail bank, International Journal of Bank Marketing, 19 (3), 12639 (2001)

11. Srivastava, K., \& Sharma, N. K.: Service Quality, Corporate Brand Image, and Switching Behavior: The Mediating Role of Customer Satisfaction and Repurchase Intention, Services Marketing Quarterly, 34(4), 274-291 (2013)

12. Wu, H. C.: An Empirical Study of the Effects of Service Quality, Perceived Value, Corporate Image, and Customer Satisfaction on Behavioral Intentions in the Taiwan Quick Service Restaurant Industry, Journal of Quality Assurance in Hospitality \& Tourism, 14(4), 36 (2013)

13. Ishaq, M. I., Bhutta, M. H., Hamayun, A. A., Danish, R. Q., \& Hussain, N. M.: Role of corporate image, product quality and customer value in customer loyalty: Intervening effect of customer satisfaction, Journal of Basic Applied Science Research, 4(4), 89-97 (2014)

14. Levesque, T. and McDougall, G. H. G.: Determinants of customer satisfaction in retail banking, International Journal of Bank Marketing, 14 (7), 12-20 (1996)

15. Jamal, A., and Naser, K.: Factors influencing customer satisfaction in the retail banking sector in Pakistan, International Journal of Commerce and Management, 13 (2), 29-53 (2003) 
16. Kumar, V., Smart, P. A., Maddern, H. and Maull, R. S.: Alternative Perspectives on Service Quality and Customer Satisfaction: The Role of BPM, International Journal of Service Industry Management, 19 (2), 176 - 187 (2008)

17. Chi, C. G. Q. and Qu, H.: Examining the structural relationships of destination image, tourist satisfaction and destination loyalty: An integrated approach, Tourism Management, 29 (4), 624-636 (2008)

18. Heskett, J.L., Jones, T.O., Loveman, G.W., Sasser, W.E. Jr and Schlesinger, L.A.: Putting the service-profit chain to work, Harvard Business Review, March/April, 164-74 (1994)

19. Kumar, V., Batista, L., and Maull, R.: The impact of operations performance on customer loyalty, Service Science, 3(2), 158-171 (2011)

20. Zhao, J., Wroe, C., Goble, C., Stevens, R., Quan, D. and Greenwood, M.: Using Semantic Web Technologies for Representing E-science Provenance, The Semantic Web - ISWC 2004, Lecture Notes in Computer Science, 3298, 92-106 (2004)

21. Bhappu, A. D. and Schultze, U.: The Role of Relational and Operational Performance in Business-to-Business Customers' Adoption of Self-Service Technology, Journal of Service Research, 8 (4), 372-385 (2006)

22. Minett, S.: B2B Marketing, Financial Times/Prentice-Hall, London (2002)

23. Barschel, H.: B2B Versus B2C Marketing - Major Differences Along the Supply Chain of Fast Moving Consumer Goods (FMCG), Grin Verlag, Germany (2004)

24. Homburg C. and Fürst, A.: How organizational complaint handling drives customer loyalty: an analysis of the mechanistic and the organic approach, Journal of Marketing, 69 (3), 95-114 (2005)

25. Mithas, S., Krishnan, M. S., and Fornell, C.: Why Do Customer Relationship Management Applications Affect Customer Satisfaction? Journal of Marketing, 69 (4), 201-209 (2005)

26. Rauyruen, P. and Miller, K. E.: Relationship quality as a predictor of B2B customer loyalty, Journal of Business Research, 60 (1), 21-31 (2007)

27. Tang, Y. C. Liou, F.M., and Peng, S.Y.: B2B brand extension to the B2C market-The case of the ICT industry in Taiwan, The Journal of Brand Management, 15 (6), 399-411 (2008) 28. Molinari, L. K., Abratt, R., \& Dion, P.: Satisfaction, quality and value and effects on repurchase and positive word-of-mouth behavioral intentions in a B2B services context, Journal of Services Marketing, 22(5), 363-373 (2008)

29. Rauyruen, P., Miller, K. E., \& Groth, M.: B2B services: linking service loyalty and brand equity, Journal of Services Marketing, 23(3), 175-186 (2009)

30. Gonzalez, A. E. M., Comesana, R. L., and Brea, F. A. J. C.: Assessing tourist behavioural intensions through perceived service quality and customer satisfaction, Journal of Business Research, 60, pp. 153-160 (2007)

31. Sohail, S.M.: Service quality in hospitals than you might think, Managing Service Quality, 13 (3), 197-206 (2003)

32.Chiou, S. J. and Dorge, C.: Service Quality, Trust, Specific Asset Investment, and Expertise: Direct and Indirect Effects in a Satisfaction-Loyalty Framework, Journal of Academy of Marketing Science, 34 (4), 613-627 (2006)

33. Parasuraman, A., Zeithaml, V.A. and Berry, L.L.: A conceptual model of service quality and its implications for future research, Journal of Marketing, 49, 41-50 (1985)

34. Grönroos, C.: A service quality model and its marketing implications, European Journal of Marketing, 18 (4), 36-44 (1984)

35. Lassar, M.W., Manolis, C. and Winsor, R.D.: Service quality perspectives and satisfaction in private banking, Journal of Services Marketing, 14 (3), 244-71 (2000)

36. Luk, S. T. K. and Layton, R.: Managing both Outcome and Process Quality is Critical to Quality of Hotel Service, Total Quality Management \& Business Excellence, 15 (3), 259 - 278 (2004)

37. Bell, S. J., Auh, S., and Smalley, K.: Customer Relationship Dynamics: Service Quality and Customer Loyalty in the Context of Varying Levels of Customer Expertise and Switching Costs, 
Journal of the Academy of Marketing Science, 33 (2), 169-183 (2005)

38. Rosenzweig, E. D. and Roth, A. V.: Towards a theory of competitive progression: Evidence from High-Tech Manufacturing, Production and Operations Management, 13 (4), 354-368 (2004)

39. Lai, J. Y. and Yang, C. C.: Effects of employees perceived dependability on success of enterprise applications in e-business, Industrial Marketing Management, 38 (3), 263-274 (2009) 40. Andreassen, T. W., and Lindestad, B.: Customer loyalty and complex services: the impact of corporate image on quality, customer satisfaction and loyalty for customers with varying degrees of service expertise, International Journal of Service Industry Management, 9(1), 7-23 (1998)

41. Martenson, R.: Corporate brand image, satisfaction and store loyalty: A study of the store as a brand, store brands and manufacturer brands, International Journal of Retail \& Distribution Management, 35(7), 544-555 (2007)

42. Cameran, M., Moizer, P., \& Pettinicchio, A.: Customer satisfaction, corporate image, and service quality in professional services, The Service Industries Journal, 30(3), 421-435 (2010) 43. Wu, J. H. C., Lin, Y. C., \& Hsu, F. S.: An empirical analysis of synthesizing the effects of service quality, perceived value, corporate image and customer satisfaction on behavioral intentions in the transport industry: A case of Taiwan high-speed rail, Innovative Marketing, 7(3), 83-100 (2011)

44. Meredith, J. R., Raturi, A., Amoako-Gyampah, K. \& Kaplan, B.: Alternative Research Paradigms in Operations, Journal of Operations Management, 8(4), 297-326 (1989)

45. Riege, A. M.: Validity and Reliability Tests in Case Study Research: a Literature Review with "hand-on” Applications for each Research Phase, Qualitative Market Research: An International Journal, 6(2), 75-86 (2003)

46. Bryman, A.: Social Research Methods, Oxford University Press, New York (2004) 